\title{
Hybrid true seed production from potato mother plant as influenced by nitrogen splitting and boron
}

\author{
Rajesh Chakraborty, Shahidul Islam, Tuhin Suvra Roy \\ Department of Agronomy, Faculty of Agriculture, Sher-e-Bangla Agricultural University, Dhaka, Bangladesh
}

\begin{abstract}
Experiments were conducted to show the effect of split application of nitrogen (SN) and boron (B) on hybrid True Potato Seed (TPS) production. The TPS-67 (ठ) and MF-II (q) were used as crossing materials. The experiments comprised two factors i.e., factor-A; nitrogen splitting (4 levels): 2 split ( $\mathrm{SN}_{0}$-Conventional), 3 split $\left(\mathrm{SN}_{1}\right), 4$ split $\left(\mathrm{SN}_{2}\right)$ and 5 split $\left(\mathrm{SN}_{3}\right)$ where $50 \mathrm{~kg} \mathrm{~N} \mathrm{ha}{ }^{-1}$ applied as basal from total $300 \mathrm{~kg} \mathrm{~N} \mathrm{ha}^{-1}$ with each split application and the rest $250 \mathrm{~kg} \mathrm{~N} \mathrm{ha}^{-1}$ was splitted as per treatment at 10 days intervals started from 30 DAP (days after planting); and factor-B; boron (4 levels): $0\left(\mathrm{~B}_{0}\right), 4\left(\mathrm{~B}_{1}\right), 6\left(\mathrm{~B}_{2}\right)$ and $8\left(\mathrm{~B}_{3}\right) \mathrm{kg} \mathrm{B} \mathrm{ha}{ }^{-1}$ under split-plot design with three replications. We found that $\mathrm{SN}$ and/or B influenced the hybrid TPS production. The maximum yield $(2160.1 \mathrm{mg})$ of TPS plant ${ }^{-1}$ was found from $\mathrm{SN}_{1} \mathrm{~B}_{3}$ and the minimum (1001.8 mg) was in $\mathrm{SN}_{0} \mathrm{~B}_{0}$. The maximum yield (172.81
\end{abstract}

Correspondence: Tuhin Suvra Roy, Department of Agronomy, Faculty of Agriculture, Sher-e-Bangla Agricultural University, Dhaka-1207, Bangladesh

Tel.: +8801710515090

E-mail: tuhinsuvra2002@yahoo.com

Key words: True Potato Seed Yield, 100-Seed weight, potato mother plant

Conflict of Interest: The authors declare no potential conflict of interest.

Funding: The authors are very much grateful to the Ministry of Education for the financial support of the study.

Acknowledgment: The authors gratefully acknowledge the Ministry of Education, the People's Republic of Bangladesh for financial support on present research work

Dedication: The authors would like to dedicate their present piece of research to the farming communities of hunger world.

Received for publication: 14 September 2019.

Accepted for publication: 25 February 2020.

COpyright: the Author(s), 2020

Licensee PAGEPress, Italy

Journal of Biological Research 2020; 93:8563

doi:10.4081/jbr.2020.8563

This article is distributed under the terms of the Creative Commons Attribution Noncommercial License (by-nc 4.0) which permits any noncommercial use, distribution, and reproduction in any medium, provided the original author(s) and source are credited. $\mathrm{kg}$ ) of TPS ha ${ }^{-1}$ was found from $\mathrm{SN}_{1} \mathrm{~B}_{3}$ and the minimum (80.14 $\mathrm{kg}$ ) was in $\mathrm{SN}_{0} \mathrm{~B}_{0}$. The maximum weight $(86.87 \mathrm{mg})$ of 100 -TPS was found from $\mathrm{SN}_{3} \mathrm{~B}_{3}$; whereas, the minimum $(53.36 \mathrm{mg}$ ) was in $\mathrm{SN}_{0} \mathrm{~B}_{0}$.

\section{Introduction}

Potato (Solanum tuberosum) is a starchy food crop ranked $4^{\text {th }}$ in the world after wheat, rice, and maize. In Bangladesh, it ranks $2^{\text {nd }}$ after rice in production. Bangladesh is the $7^{\text {th }}$ potato production country in the world ${ }^{1}$ produced $10,215,957.00$ metric tons with an average yield of $20.44 \mathrm{t} \mathrm{ha}^{-1} .^{1}$ In Bangladesh the production of potato is increasing day by day due to the increasing trends in demand and also in consumption. But, the yield of potato (20.44 $\mathrm{t} \mathrm{ha}^{-1}$ ) is very low in Bangladesh compared to other potato growing countries like New Zealand (49.31 $\left.\mathrm{t} \mathrm{ha}^{-1}\right)$, Netherlands (45.97 $\mathrm{t} \mathrm{ha}^{-1}$ ), USA (48.23 $\left.\mathrm{t} \mathrm{ha}^{-1}\right)$, Japan (29.27 $\mathrm{t} \mathrm{ha}^{-1}$ ), and India (22.31 $\left.\mathrm{t} \mathrm{ha}^{-1}\right)^{1}$. Lack of quality seeds, high cost of quality seed, unavailability and uneven distribution of certified seeds, and use of indigenous cultivars having low yield potential may be reasons for this low yield of potato. ${ }^{2}$ The gap between seed demand and supply is very high in our country due to lower seed production by the government and non-government sector through conventional system. But adoption of True Potato Seed (TPS) technology may be a better alternative to produce a huge amount of seed through fertilizer management for higher potato production. Flowering and subsequent reproductive growth, including the formation of gametophytes are directly affected by nutrient content of the mother plant for the production of quality TPS. ${ }^{3}$ Seed physiologists reported that higher level of Nitrogen $(\mathrm{N})$ is required as supplementation for seed production than the production of tuber and application of higher $\mathrm{N}$ increases shoot biomass, enhances the bloom of potato mother plants, increase pollen germination, improves seed yield and vigor. ${ }^{4}$ The weight of TPS also affected by the application of nitrogen, ${ }^{5}$ which is used by the seed scientist to select high-yielding progenies. ${ }^{6}$ To "split apply" nitrogen, growers gives opportunity to plant for up taking of two or more time nutrient during the growing season rather than providing all of the crop $\mathrm{N}$ requirements with a single treatment before or during planting. When all of the nitrogen is supplied ahead of different growth duration of crop, more of the nitrogen is susceptible to loss through denitrification, leaching, or volatilization. ${ }^{7}$ The growth of pollen tube and anther development is also sensitive to boron deprivation. ${ }^{8}$ The primary function of boron is developing the cell wall structure of pollen tubes and in its absence pollen tube may burst. ${ }^{9}$ In addition to male sterility, pistil sterility is another alteration of the reproductive system due to boron deficiency, ${ }^{10}$ although boron requirement is minor than in the male 
organs. ${ }^{11}$ In tomato, boron fertilization has greater photosynthetic activity resulting increased production and retention of flowers and fruits, which increased number and weight of fruits. ${ }^{12}$ Day ${ }^{13}$ stated that, it may be attributed to the effect of boron in IAA metabolism which increases the number of flowers and stimulates the phosphorus uptake by roots of plants which in turn promoted the development of flower clusters and exhibited a favorable effect on retention of flowers. ${ }^{14}$ It also influences the fruit formation, ${ }^{15}$ fruit development and seed development. ${ }^{16}$ Boron deficiency causes a delay in pollen germination and pollen tube development and ultimately it halts flowering and fruit setting. ${ }^{17}$ Stanley ${ }^{18}$ reported that the translocation of sugar, starches, nitrogen and, phosphorus, synthesis of amino acids and proteins were affected by boron deficiencies. The use of TPS technology may reduce the cost of small and marginal farmers as a supplementation to the traditional use of seed tubers in potato production. ${ }^{19}$ However, the production of quality TPS under optimum agronomic management with fertilizers application on potato mother plants have not been well studied in our country with the most promising parental lines ( $q$ MF-II and o TPS-67). Therefore, the experiments were conducted to determine the most promising combination from the split application of $\mathrm{N}$ and $\mathrm{B}$ for higher yield of hybrid TPS.

\section{Materials and Methods}

\section{Study area}

Sher-e-Bangla Agricultural University is situated between 23.771 and 90.375 latitude and longitude, respectively and 13.72 meters high from sea levels. Upper-level $(0-10 \mathrm{~cm})$ soils were clay loam in texture, olive-gray in color having fine to medium distinct dark yellowish-brown mottles which belonged by Madhupur Tract (Agro-ecological Zone-28). ${ }^{20}$ The selected plot was situated above the flood level. Proper irrigation and drainage system was prepared during the experimental period. The soil of experimental field was characterized by $25 \%$ sand, $20 \%$ silt, $55 \%$ clay, $0.47 \%$ organic carbon, 19.92 ppm available P and $0.13 \mathrm{meq} / 100 \mathrm{~g}$ soil exchangeable K. Analytical result of other soil constituents were presented in Table 1.

\section{Weather condition during the experimental period}

The experimental area is situated in sub-tropical climatic zone characterized by heavy rainfall during pre-monsoon (March to May-Kharif-I), monsoon period (June to September-Kharif-II season) and scanty rainfall during the rest period of the year. The Rabi season (October to March) is characterized by comparatively low temperature and plenty of sunshine from November to February. During the period of study detailed meteorological data was collected from the Meteorological station of Sher-e-Bangla Agricultural University, Dhaka in respect of air temperature, relative humidity and total rainfall those were presented in Table 2.

\section{Planting materials}

The tubers of both parental line, TPS-67 (as a male parent, §) and MF-II (as a female parent, 9 ) were collected from BADC farm, Domar, Dinajpur, Bangladesh. The female line MF II is tuberosum and male line TPS 67 is andigena based. ${ }^{21}$ No promising line had been released after MF II and TPS 67 in our country for TPS production. So, these two parental lines were used for their good combining ability for selfing to produce quality TPS. ${ }^{22}$

\section{Experimental design and treatment implementation}

The experimental treatment comprised two factors i.e., Nitrogen Splitting (SN) and Boron levels (B) which are presented as follows.

\section{Nitrogen Splitting (SN)}

$\mathrm{SN}_{0}: 2$ split (Conventional); $\mathrm{SN}_{1}: 3$ split; $\mathrm{SN}_{2}: 4$ split and $\mathrm{SN}_{3}$ : 5 split applications of $\mathrm{N}$ where $50 \mathrm{~kg} \mathrm{~N} \mathrm{ha}^{-1}$ applied as basal from total $300 \mathrm{~kg} \mathrm{~N} \mathrm{ha}^{-1}$ with each split and the rest $250 \mathrm{~kg} \mathrm{~N} \mathrm{ha}^{-1}$ was

Table 1. Analytical data of soil before planting of mother tuber and after harvest of final berry (Mean data from two-year experiments).

\begin{tabular}{|c|c|c|c|c|c|c|}
\hline $\begin{array}{l}\text { Nitrogen } \\
\text { splitting } \\
\times \text { Boron }\end{array}$ & $\begin{array}{c}\text { Total Nitrogen (\%) } \\
\text { (Critical Level: 0.05-0.2) }\end{array}$ & $\begin{array}{c}\text { Before planting } \\
\text { Total Boron ( } \mu \mathrm{g} / \mathrm{g} \text { soil) } \\
\text { (Critical Level: } 0.5-1.0 \mu \mathrm{g} / \mathrm{g} \text { ) }\end{array}$ & pH Level & $\begin{array}{c}\text { Total Nitrogen } \\
\text { (\%) }\end{array}$ & $\begin{array}{l}\text { After harvest } \\
\text { Total Boron } \\
\text { (jg/g soil) }\end{array}$ & pH Level \\
\hline $\mathrm{SN}_{0} \mathrm{~B}_{0}$ & 0.052 & 0.193 & 5.57 & 0.035 & 0.177 & 5.55 \\
\hline $\mathrm{SN}_{0} \mathrm{~B}_{1}$ & 0.051 & 0.188 & 5.56 & 0.036 & 0.195 & 5.54 \\
\hline $\mathrm{SN}_{0} \mathrm{~B}_{2}$ & 0.050 & 0.185 & 5.57 & 0.035 & 0.189 & 5.53 \\
\hline $\mathrm{SN}_{0} \mathrm{~B}_{3}$ & 0.051 & 0.184 & 5.55 & 0.034 & 0.186 & 5.51 \\
\hline $\mathrm{SN}_{1} \mathrm{~B}_{0}$ & 0.053 & 0.190 & 5.56 & 0.049 & 0.183 & 5.52 \\
\hline $\mathrm{SN}_{1} \mathrm{~B}_{1}$ & 0.054 & 0.185 & 5.55 & 0.051 & 0.188 & 5.51 \\
\hline $\mathrm{SN}_{1} \mathrm{~B}_{2}$ & 0.052 & 0.191 & 5.58 & 0.053 & 0.209 & 5.54 \\
\hline $\mathrm{SN}_{1} \mathrm{~B}_{3}$ & 0.051 & 0.194 & 5.57 & 0.056 & 0.245 & 5.52 \\
\hline $\mathrm{SN}_{2} \mathrm{~B}_{0}$ & 0.052 & 0.183 & 5.60 & 0.059 & 0.176 & 5.55 \\
\hline $\mathrm{SN}_{2} \mathrm{~B}_{1}$ & 0.055 & 0.189 & 5.69 & 0.058 & 0.285 & 5.61 \\
\hline $\mathrm{SN}_{2} \mathrm{~B}_{2}$ & 0.052 & 0.187 & 5.70 & 0.063 & 0.341 & 5.64 \\
\hline $\mathrm{SN}_{2} \mathrm{~B}_{3}$ & 0.054 & 0.195 & 5.75 & 0.062 & 0.343 & 5.70 \\
\hline $\mathrm{SN}_{3} \mathrm{~B}_{0}$ & 0.054 & 0.186 & 5.75 & 0.061 & 0.289 & 5.71 \\
\hline $\mathrm{SN}_{3} \mathrm{~B}_{1}$ & 0.053 & 0.187 & 5.72 & 0.060 & 0.331 & 5.66 \\
\hline $\mathrm{SN}_{3} \mathrm{~B}_{2}$ & 0.054 & 0.183 & 5.75 & 0.061 & 0.339 & 5.71 \\
\hline $\mathrm{SN}_{3} \mathrm{~B}_{3}$ & 0.055 & 0.191 & 5.73 & 0.064 & 0.345 & 5.70 \\
\hline
\end{tabular}


splitted as per treatment at 10 days intervals started from 30 DAP (days after planting).

\section{Boron (B)}

$\mathrm{B}_{0}: 0 \mathrm{~kg} \mathrm{~B} \mathrm{ha}{ }^{-1}, \mathrm{~B}_{1}: 4 \mathrm{~kg} \mathrm{~B} \mathrm{ha}{ }^{-1}, \mathrm{~B}_{2}: 6 \mathrm{~kg} \mathrm{~B} \mathrm{ha}{ }^{-1}, \mathrm{~B}_{3}: 8 \mathrm{~kg} \mathrm{~B} \mathrm{ha}{ }^{-1}$

Split-plot design was chosen for the experiments with three replications. Nitrogen splitting and boron levels were assigned to main and sub-plot, respectively. ${ }^{23}$ The size of the unit plot was 1.5 $\mathrm{m} \times 1.0 \mathrm{~m}$, where replication to replication and plot to plot distance was 1.0 and $1.0 \mathrm{~m}$, respectively.

\section{Crop husbandry}

The experimental area was opened by power tiller at the last week of October 2013 and 2014. Fertilizer such as Urea, TSP, MoP, Gypsum, Borax, and $\mathrm{ZnSO}_{4}$ was used as a source of $\mathrm{N}, \mathrm{P}, \mathrm{K}, \mathrm{S}, \mathrm{B}$, and $\mathrm{Zn}$, respectively. Fifty (50) $\mathrm{kg}$ of $\mathrm{N}$ and full amount of other fertilizers along with cow dung were applied as basal irrespective of treatments. The remaining quantity of $\mathrm{N}$ was applied at 10 -day intervals as per treatment, ${ }^{24}$ started from just before blooming (30 days after planting). On 1 November 2013 and 2014, well-sprouted and uniform sized (60-70 g) seed tuber of the female parent was planted with a spacing of $0.5 \mathrm{~m} \times 0.25 \mathrm{~m}$ in a plot of $1.5 \mathrm{~m} \times 1.0 \mathrm{~m}$ size. The plants emerged from tuber were not ridged as followed in standard potato production. Male plants were planted in separate plot at least 7 days (on 25 October, 2013 and 2014) earlier than female plant to harmonize their flowering for pollination purposes. Two earthing up were done at 30 and 50 DAP, respectively. True Potato Seed (TPS) production needs more water than normal tuber production for supplying proper moisture for vigorous growth. Water was applied by using watering can as per requirement. To manage the female plant easily two stems hill ${ }^{-1}$ were kept. To extend the photoperiod (9 to 14 hours) a 200-watt white florescent bulb was provided (Figure 1) from $25 \mathrm{DAP}$ and continued till completion of harvesting of berries to give the light intensity in the range of 30,000 to 50,000 lux on the plant surface to induce profuse flowering and berry sets. ${ }^{25}$ To get the best quality TPS, flowers of primary and secondary inflorescence were considered. The female parent was hand-pollinated (named as artificial pollination for TPS production) at morning (9.00 am-11.00 am) by using the collected pollen grains from male parent (Figure 2) for proper assurance of fertilization. Well ripened soft berries were used to collect the seed. The method of seed extraction was as same as the method described by Roy. ${ }^{24}$ Thereafter, the seeds were weighed.

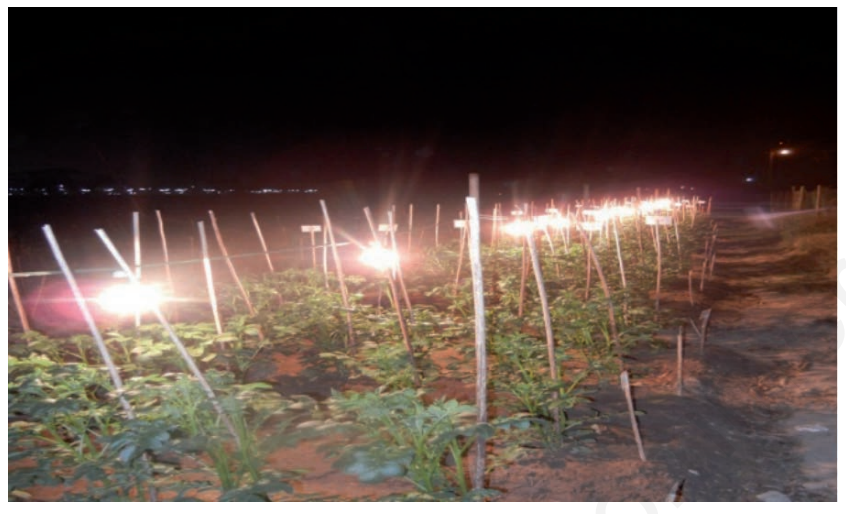

Figure 1. Extended photoperiod through artificial lightening at night $(30,000-50,000$ lux $)$.

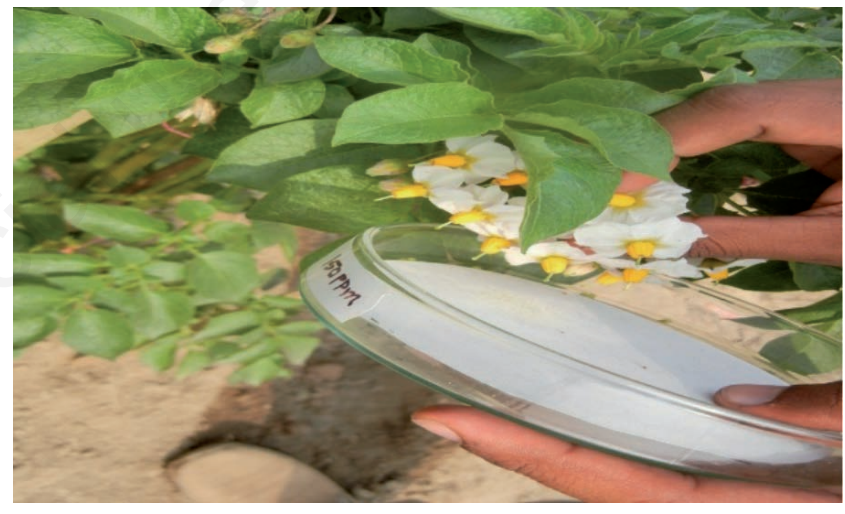

Figure 2. Artificial pollination of female flowers from MF-II ( $(+)$ with pollen grains of TPS-67 $\left({ }^{\pi}\right)$.

Table 2. Weather data on temperature, relative humidity and total rainfall

\begin{tabular}{|c|c|c|c|c|c|}
\hline Year & Month & \multicolumn{2}{|c|}{ Temperature $\left({ }^{\circ} \mathrm{C}\right)$} & $\begin{array}{l}\text { Relative humidity } \\
\qquad(\%)\end{array}$ & $\begin{array}{l}\text { Total rainfall } \\
\text { (mm) }\end{array}$ \\
\hline \multirow[t]{7}{*}{ 2013-2014 } & October & 30.18 & 14.85 & 67.82 & 1.40 \\
\hline & November & 28.13 & 6.88 & 58.18 & 0.52 \\
\hline & December & 25.36 & 5.21 & 54.30 & 0.21 \\
\hline & January & 28.10 & 11.05 & 69.48 & 8.00 \\
\hline & February & 28.00 & 12.09 & 79.13 & 32.00 \\
\hline & March & 34.12 & 17.05 & 70.07 & 61.00 \\
\hline & April & 36.37 & 18.03 & 73.31 & 65.11 \\
\hline \multirow[t]{7}{*}{ 2014-2015 } & October & 32.11 & 13.31 & 65.21 & 1.29 \\
\hline & November & 28.56 & 12.28 & 62.09 & 3.51 \\
\hline & December & 25.02 & 9.82 & 55.84 & 5.09 \\
\hline & January & 23.81 & 11.02 & 50.03 & 1.10 \\
\hline & February & 26.08 & 14.55 & 44.59 & 14.98 \\
\hline & March & 29.58 & 17.29 & 46.19 & 44.96 \\
\hline & April & 36.71 & 28.21 & 59.89 & 105.32 \\
\hline
\end{tabular}




\section{Parameters studied}

\section{Number of TPS berr ${ }^{y-1}$}

Collected berries were packed separately for each plot with subjective treatment and then extraction of true seeds was done properly and then seeds were counted against each berry of different sizes.

\section{Yield of TPS $\mathrm{kg}^{-1}$ of berry (g)}

One kg berry was packed separately for each plot and extraction of seed was done properly to weigh the total yield of TPS $\mathrm{kg}^{-}$ ${ }^{1}$ berry in gram unit.

\section{Total yield of TPS plant ${ }^{-1}$ (mg)}

Five plants were randomly selected against each plot and the collected berries were packed separately for each plant. The extraction was done properly to weigh the TPS plant ${ }^{-1}$ and finally the means were taken in terms of milligram unit.

\section{Total yield of TPS ( $\left.\mathrm{kg} \mathrm{ha}^{-1}\right)$}

The yield of true seed plant ${ }^{-1}$ was converted to plot $^{-1}$ then finally converted to $\mathrm{ha}^{-1}$.

\section{Weight of 100-TPS (mg)}

Hundred numbers of TPS were taken against each treatment to weigh in terms of milligram unit by using electric balance.
Pearson correlation coefficient (r) was calculated among different yield traits of hybrid TPS by using MS Excel spreadsheet.

\section{Statistical package used}

Following the analysis of variance technique (ANOVA), the data obtained for different characters were statistically analyzed by using the F-test through Statistix 10 (2013) computer program and the treatment means were separated by Least Significant Difference (LSD) test at $\mathrm{p} \leq 0.05 .^{23}$

\section{Results and Discussion}

\section{Number of TPS berry ${ }^{-1}$ at different berry sizes}

\section{Effect of nitrogen splitting}

A significant $(\mathrm{p} \leq 0.01)$ variation was noted among the different split application of $\mathrm{N}$ in case of number of TPS berry ${ }^{-1}$ at different berry sizes (Figure 3A). In case of TPS in small-sized berry, the maximum number was found from $\mathrm{SN}_{1}$ (71.49) and thereafter decreased the seed number berry ${ }^{-1}$ with the increasing rates of nitrogen splitting and the minimum number was found from $\mathrm{SN}_{3}$ (52.74). In case of TPS in medium-sized berry, a gradual increasing trend was found in case of number of seed berry ${ }^{-1}$ with the
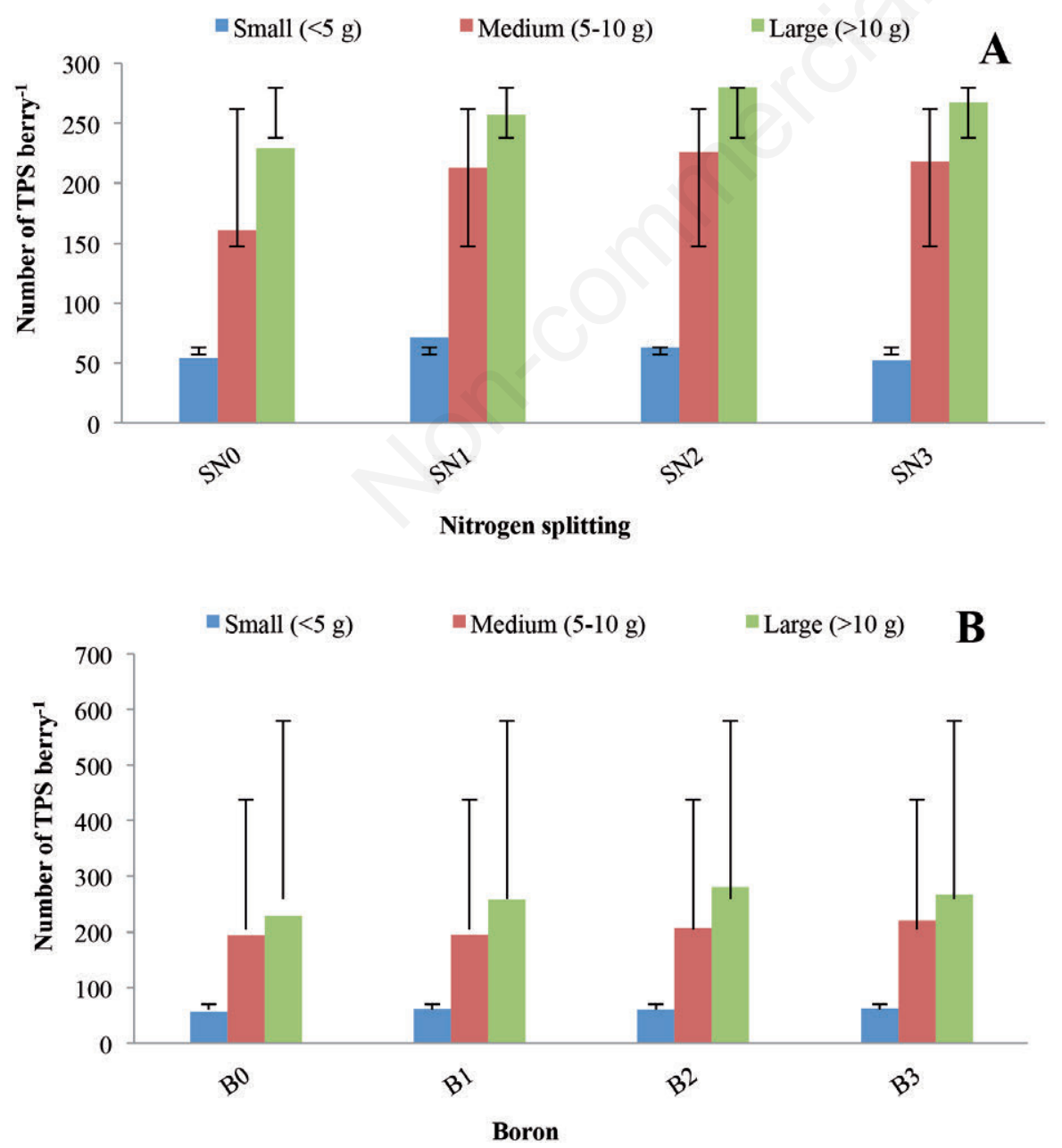

Figure 3. Effect of nitrogen splitting (A) and Boron (B) on number of TPS berry ${ }^{-1}$ at different berry sizes in potato mother plant (LSD value $0.35,1.93$ and 0.96 for TPS in small, medium and large sized berry, respectively under nitrogen splitting and LSD value 4.63, 19.10 and 14.78 for TPS in small, medium and large sized berry, respectively under for Boron doses). $\mathrm{SN}_{0}=2$ split dose (conventional); $\mathrm{SN}_{1}=3$ split dose; $\mathrm{SN}_{2}=4$ split dose; $\mathrm{SN}_{3}=5$ split dose; $B_{0}=0 \mathrm{~kg} \mathrm{~B} \mathrm{ha}^{-1} ; B_{1}=4 \mathrm{~kg} B$ $\mathrm{ha}^{-1} ; \mathrm{B}_{2}=6 \mathrm{~kg} \mathrm{~B} \mathrm{ha}^{-1} ; \mathrm{B}_{3}=8 \mathrm{~kg} \mathrm{~B} \mathrm{ha}^{-1}$. 
increasing of split application of $\mathrm{N}$ up to $\mathrm{SN}_{2}$ treatment. The maximum number of TPS berry ${ }^{-1}$ was found from $\mathrm{SN}_{2}$ (226.25) followed by $\mathrm{SN}_{3}$ (218.00) and the minimum from $\mathrm{SN}_{0}$ (160.75). In case of TPS in large-sized berry, a gradual increasing trend was found in case of number of seed berry ${ }^{-1}$ with the increasing of split application of $\mathrm{N}$ up to $\mathrm{SN}_{2}$ treatment. The maximum number of TPS berry ${ }^{-1}$ was found from $\mathrm{SN}_{2}$ (280.25) followed by $\mathrm{SN}_{3}$ (267.50) and the minimum from $\mathrm{SN}_{0}$ (229.25). Different rates of food partitioning in different sized berry and higher portioning in larger sized berry may be reason of such differences found in TPS number berry ${ }^{-1}$ of different sizes.

\section{Effect of boron}

In respect of number of TPS in small-sized berry, a non-significant effect was found due to different B levels (Figure 3B). A significant $(p \leq 0.05)$ variation was noted in case of TPS in mediumsized berry and an increasing trend was found on the number of seed berry ${ }^{-1}$ with the increasing of boron (Figure $4 \mathrm{~B}$ ). The maximum number (220.50) of TPS berry ${ }^{-1}$ was found from $\mathrm{B}_{3}$ which was statistically similar (207.50) to $\mathrm{B}_{2}$ and the minimum (194.50) was in $\mathrm{B}_{0}$. In case of TPS in large-sized berry, there was a significant $(\mathrm{p} \leq 0.01)$ variation was noted and a gradually increasing trend was found on the number of seed berry ${ }^{-1}$ with the increasing of boron (Figure 4B). The maximum number (279.50) of TPS berry ${ }^{-}$ ${ }^{1}$ was found from $B_{3}$ followed by $B_{2}(261.50)$ and the minimum (245.50) was in $\mathrm{B}_{0}$.

\section{Combined effect of nitrogen splitting and boron}

Significant $(\mathrm{p} \leq 0.01$ and $\mathrm{p} \leq 0.05)$ variation was found among different combinations of split application of $\mathrm{N}$ and $\mathrm{B}$ in respects of number of TPS berry ${ }^{-1}$ at different berry sizes (Table 3 ). In case of number of TPS in small-sized berry, the maximum number (77.99) of TPS berry ${ }^{-1}$ was found from $\mathrm{SN}_{1} \mathrm{~B}_{2}$ which was statistically similar to $\mathrm{SN}_{1} \mathrm{~B}_{3}$ (76.99), $\mathrm{SN}_{2} \mathrm{~B}_{0}$ (72.99) and $\mathrm{SN}_{1} \mathrm{~B}_{1}$ (68.99). The minimum number (50.00) was found from $\mathrm{SN}_{3} \mathrm{~B}_{2}$. In case of
TPS in medium-sized berry, the maximum number (249.00) of TPS berry ${ }^{-1}$ was found from $\mathrm{SN}_{3} \mathrm{~B}_{3}$ which was statistically similar to $\mathrm{SN}_{1} \mathrm{~B}_{2}$ (243.00), $\mathrm{SN}_{2} \mathrm{~B}_{3}$ (240.00), $\mathrm{SN}_{2} \mathrm{~B}_{3}$ (238.00), $\mathrm{SN}_{3} \mathrm{~B}_{1}$ (221.00) and $\mathrm{SN}_{3} \mathrm{~B}_{0}$ (220.00). The minimum number of TPS (143.00) in medium sized berry was found $\mathrm{SN}_{0} \mathrm{~B}_{0}$. In the case of TPS in large-sized berry, the maximum number (316.00) of TPS berry ${ }^{-1}$ was found from $\mathrm{SN}_{3} \mathrm{~B}_{3}$ which was statistically similar to $\mathrm{SN}_{2} \mathrm{~B}_{3}$ (297.00) and $\mathrm{SN}_{2} \mathrm{~B}_{2}$ (295.00). The minimum number of TPS (213.00) in large sized berry was found $\mathrm{SN}_{0} \mathrm{~B}_{0}$.

\section{Yield of TPS kg-1 berry (g)}

A profound $(\mathrm{p} \leq 0.01)$ variation was found in case of yield of TPS kg-1 berry (g) due to nitrogen splitting (Figure 4A). The yield was increased with increasing of the splitting of $\mathrm{N}$ up to $\mathrm{SN}_{2}$ treatment and thereafter slightly decreased with the increasing of split application. The maximum TPS yield $(23.49 \mathrm{~g})$ was found from $\mathrm{SN}_{2}$ followed by $\mathrm{SN}_{3}(22.53 \mathrm{~g})$ and the minimum (17.15 g) was in $\mathrm{SN}_{0}$. Significant $(\mathrm{p} \leq 0.01)$ variation was noted among boron doses in case of yield of TPS $\mathrm{kg}^{-1}$ berry ( $\mathrm{g}$ ) (Figure 4B). The yield was increased with the increasing of $\mathrm{B}$. The maximum TPS yield $(24.07 \mathrm{~g})$ was found from $\mathrm{B}_{3}$ followed by $\mathrm{B}_{2}(20.49 \mathrm{~g}), \mathrm{B}_{1}(19.64 \mathrm{~g})$ and the minimum $(18.87 \mathrm{~g})$ was in $\mathrm{B}_{0}$. Significant $(\mathrm{p} \leq 0.01)$ variation was found among different combinations of split application of $\mathrm{N}$ and $\mathrm{B}$ in respect of the yield of TPS $\mathrm{kg}^{-1}$ berry (g) (Table 3 ). The maximum yield (29.09 g) of TPS was found from $\mathrm{SN}_{3} \mathrm{~B}_{3}$ combination which was statistically similar to $\mathrm{SN}_{2} \mathrm{~B}_{3}$ (27.86) combination and the minimum (14.81) was in $\mathrm{SN}_{0} \mathrm{~B}_{0}$.

\section{Total yield of TPS plant ${ }^{-1}(\mathbf{m g})$}

In aspect of total yield of TPS plant ${ }^{-1}(\mathrm{mg})$ a remarkable $(p \leq 0.01)$ variation was noted among the different split application of $\mathrm{N}$ (Figure 5A). A gradual decreasing trend was exhibited with the increasing of split doses of $\mathrm{N}$ from $\mathrm{SN}_{1}$ towards ahead of splitting number. The maximum TPS yield $(1838.6 \mathrm{mg}$ ) was found

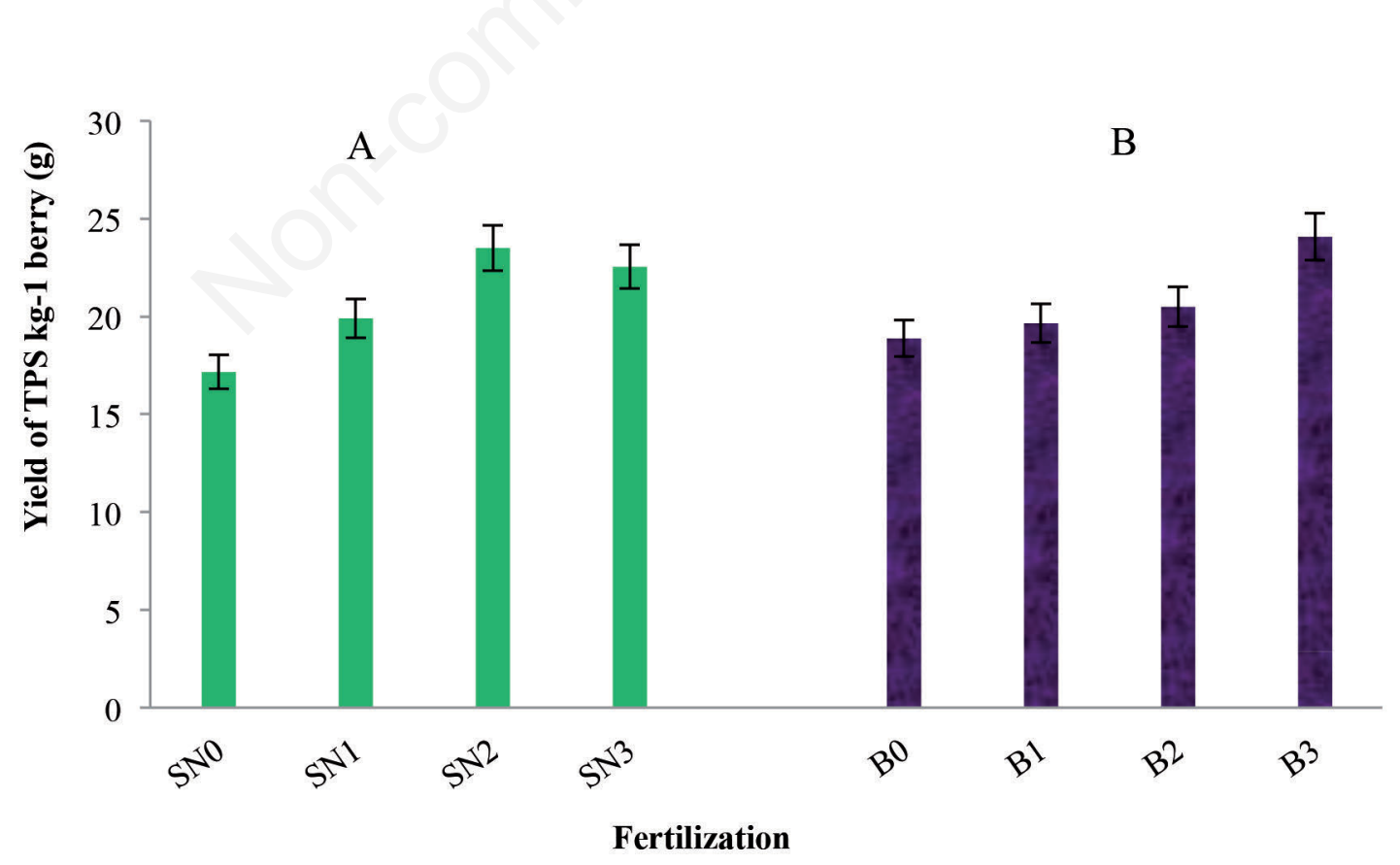

Figure 4. Effect of nitrogen splitting (A) and boron (B) on yield of TPS kg-1 berry (g) of potato mother plant (LSD value 0.15 and 1.68 for $S N$ and $B$, respectively). $S N_{0}=2$ split dose (conventional); $S N_{1}=3$ split dose; $S N_{2}=4$ split dose; $S N_{3}=5$ split dose; $B_{0}=0 \mathrm{~kg} B \mathrm{ha}^{-1}, B_{1}=4$ $\mathrm{kg} \mathrm{B} \mathrm{ha}^{-1} ; \mathrm{B}_{2}=6 \mathrm{~kg} \mathrm{~B} \mathrm{ha}^{-1} ; \mathrm{B}_{3}=8 \mathrm{~kg} \mathrm{~B} \mathrm{ha}^{-1}$. 
from $\mathrm{SN}_{1}$ followed by $\mathrm{SN}_{2}(1594.9 \mathrm{mg})$ and the minimum (1340.0 $\mathrm{mg})$ was in $\mathrm{SN}_{0}$. Profound $(\mathrm{p} \leq 0.05)$ variation was noted among different levels of boron application in respect of the total yield of TPS plant ${ }^{-1}$ (mg) (Figure 5B). A gradual increasing trend was found with the increasing of boron doses. The maximum TPS yield $\left(1648.3 \mathrm{mg}\right.$ ) was found from $\mathrm{B}_{3}$ which was statistically similar to
$\mathrm{B}_{2}$ (1549.4 mg), $\mathrm{B}_{1}(1524.6 \mathrm{mg})$ and the minimum (1456.6 mg) was in $B_{0}$. Profound $(p \leq 0.01)$ variation was noted among different combinations of split application of $\mathrm{N}$ and $\mathrm{B}$ in respect of the total yield of TPS plant ${ }^{-1}(\mathrm{mg})$ (Table 3$)$. The maximum yield (2160.1 $\mathrm{mg}$ ) of TPS was found from $\mathrm{SN}_{1} \mathrm{~B}_{3}$ and the minimum yield (1001.8 $\mathrm{mg}$ ) was in $\mathrm{SN}_{0} \mathrm{~B}_{0}$.

Table 3. Combined effect of nitrogen splitting and boron on number of TPS berry-1 at different berry sizes, yield and yield contributing traits in potato mother plant (Mean data from two-year experiments)

\begin{tabular}{|c|c|c|c|c|c|c|c|}
\hline $\begin{array}{l}\text { Nitrogen } \\
\text { Splitting } \\
\times \text { Boron }\end{array}$ & $\begin{array}{l}\text { Number of TPS } \\
\text { Small } \\
(<5 \mathrm{~g})\end{array}$ & $\begin{array}{l}\text { berry }{ }^{-1} \text { at diff } \\
\text { Medium } \\
(5-10 \mathrm{~g})\end{array}$ & $\begin{array}{l}\text { ent berry sizes } \\
\text { Large } \\
(>10 \mathrm{~g})\end{array}$ & $\begin{array}{l}\text { Yield of TPS } \\
\mathrm{kg}^{-1} \text { berry (g) }\end{array}$ & $\begin{array}{l}\text { Total yield of TPS } \\
\text { plant }^{-1}(\mathrm{mg})\end{array}$ & $\begin{array}{l}\text { Total yield of TPS } \\
\qquad\left(\mathrm{kg} \mathrm{ha}^{-1}\right)\end{array}$ & $\begin{array}{l}\text { Wt. of 100-TPS } \\
\text { (mg) }\end{array}$ \\
\hline $\mathrm{SN}_{0} \mathrm{~B}_{0}$ & $40.00 \mathrm{~h}$ & $143.00 \mathrm{i}$ & $213.00 \mathrm{~g}$ & $14.81 \mathrm{f}$ & $1001.80 \mathrm{~g}$ & $80.14 \mathrm{~g}$ & $53.36 \mathrm{e}$ \\
\hline $\mathrm{SN}_{0} \mathrm{~B}_{1}$ & $53.99 \mathrm{~d}-\mathrm{g}$ & 155.00 hi & $229.00 \mathrm{fg}$ & $17.08 \mathrm{ef}$ & $1324.30 \mathrm{f}$ & $105.94 \mathrm{f}$ & $71.66 \mathrm{~d}$ \\
\hline $\mathrm{SN}_{0} \mathrm{~B}_{2}$ & 58.99 d-f & $167.00 \mathrm{~g}-\mathrm{i}$ & 235.00 e-g & $18.16 \mathrm{~d}-\mathrm{f}$ & 1473.70 d-f & $117.90 \mathrm{~d}-\mathrm{f}$ & $74.04 \mathrm{~cd}$ \\
\hline $\mathrm{SN}_{0} \mathrm{~B}_{3}$ & $62.99 \mathrm{~cd}$ & $178.00 \mathrm{f}-\mathrm{i}$ & $240.00 \mathrm{~d}-\mathrm{g}$ & $18.56 \mathrm{c}-\mathrm{e}$ & $1560.20 \mathrm{c}-\mathrm{f}$ & $124.82 \mathrm{c}-\mathrm{f}$ & $74.75 \mathrm{~cd}$ \\
\hline $\mathrm{SN}_{1} \mathrm{~B}_{0}$ & 61.99 c-e & $193.00 \mathrm{~d}-\mathrm{g}$ & $245.00 \mathrm{c}-\mathrm{f}$ & 19.03 c-e & 1630.20 b-e & 130.42 b-e & $75.18 \mathrm{~cd}$ \\
\hline $\mathrm{SN}_{1} \mathrm{~B}_{1}$ & $68.97 \mathrm{a}-\mathrm{c}$ & $201.00 \mathrm{~d}-\mathrm{f}$ & $251.00 \mathrm{c}-\mathrm{f}$ & $19.77 \mathrm{c}-\mathrm{e}$ & 1680.20 b-d & 134.42 b-d & $76.07 \mathrm{~b}-\mathrm{d}$ \\
\hline $\mathrm{SN}_{1} \mathrm{~B}_{2}$ & 77.99 a & $243.00 \mathrm{ab}$ & $268.00 \mathrm{c}$ & $20.01 \mathrm{~cd}$ & $1883.80 \mathrm{~b}$ & $150.70 \mathrm{~b}$ & 75.98 b-d \\
\hline $\mathrm{SN}_{1} \mathrm{~B}_{3}$ & $76.99 \mathrm{a}$ & 215.00 b-e & $265.00 \mathrm{~cd}$ & $20.77 \mathrm{~cd}$ & $2160.10 \mathrm{a}$ & $172.81 \mathrm{a}$ & 77.01 b-d \\
\hline $\mathrm{SN}_{2} \mathrm{~B}_{0}$ & $72.99 \mathrm{ab}$ & $222.00 \mathrm{a}-\mathrm{d}$ & $270.00 \mathrm{bc}$ & 21.08 bc & $1733.50 \mathrm{bc}$ & 138.68 bc & 77.22 b-d \\
\hline $\mathrm{SN}_{2} \mathrm{~B}_{1}$ & 67.99 bc & $205.00 \mathrm{c}-\mathrm{f}$ & 259.00 c-e & $20.88 \mathrm{~b}-\mathrm{d}$ & $1660.90 \mathrm{~b}-\mathrm{d}$ & $132.87 \mathrm{~b}-\mathrm{d}$ & $73.54 \mathrm{~cd}$ \\
\hline $\mathrm{SN}_{2} \mathrm{~B}_{2}$ & $55.00 \mathrm{~d}-\mathrm{g}$ & $238.00 \mathrm{a}-\mathrm{c}$ & $295.00 \mathrm{ab}$ & 24.14 b & $1501.50 \mathrm{c}-\mathrm{f}$ & $120.12 \mathrm{c}-\mathrm{f}$ & $82.04 \mathrm{a}-\mathrm{c}$ \\
\hline $\mathrm{SN}_{2} \mathrm{~B}_{3}$ & $55.99 \mathrm{~d}-\mathrm{g}$ & $240.00 \mathrm{a}-\mathrm{c}$ & $297.00 \mathrm{ab}$ & $27.86 \mathrm{a}$ & 1483.80 c-f & $118.70 \mathrm{c}-\mathrm{f}$ & $84.24 \mathrm{ab}$ \\
\hline $\mathrm{SN}_{3} \mathrm{~B}_{0}$ & 53.99 e-g & 220.00 a-e & $254.00 \mathrm{c}-\mathrm{f}$ & $20.56 \mathrm{~cd}$ & $1460.80 \mathrm{~d}-\mathrm{f}$ & $116.87 \mathrm{~d}-\mathrm{f}$ & $78.16 \mathrm{a}-\mathrm{d}$ \\
\hline $\mathrm{SN}_{3} \mathrm{~B}_{1}$ & $55.00 \mathrm{~d}-\mathrm{g}$ & $221.00 \mathrm{a}-\mathrm{d}$ & $252.00 \mathrm{c}-\mathrm{f}$ & $20.84 \mathrm{~cd}$ & 1433.20 ef & 114.66 ef & $79.94 \mathrm{a}-\mathrm{d}$ \\
\hline $\mathrm{SN}_{3} \mathrm{~B}_{2}$ & $50.00 \mathrm{~g}$ & 182.00 e-h & $248.00 \mathrm{c}-\mathrm{f}$ & 19.65 c-e & $1338.50 \mathrm{f}$ & $107.08 \mathrm{f}$ & $76.56 \mathrm{~b}-\mathrm{d}$ \\
\hline $\mathrm{SN}_{3} \mathrm{~B}_{3}$ & $51.99 \mathrm{fg}$ & $249.00 \mathrm{a}$ & $316.00 \mathrm{a}$ & $29.08 \mathrm{a}$ & $1389.10 \mathrm{f}$ & $111.13 \mathrm{f}$ & $86.87 \mathrm{a}$ \\
\hline CV (\%) & 9.13 & 11.09 & 6.78 & 9.61 & 9.93 & 9.93 & 7.82 \\
\hline LSD (0.05) & 8.04 & 33.14 & 25.61 & 2.91 & 224.19 & 17.93 & 8.68 \\
\hline F test & $* *$ & $*$ & $*$ & $* *$ & $* *$ & $* *$ & $*$ \\
\hline
\end{tabular}

Means followed by different letters in the same column differ significantly according to LSD test

*, F test significant at $\mathrm{P} \leq 0.05 ;{ }^{* *}, \mathrm{~F}$ test significant at $\mathrm{P} \leq 0.01 \mathrm{SN}_{0}=2$ split dose (conventional), $\mathrm{SN}_{1}=3$ split dose, $\mathrm{SN}_{2}=4$ split dose, $\mathrm{SN}_{3}=5$ split dose; $\mathrm{B}_{0}=0 \mathrm{~kg} B$ ha ${ }^{-1}, \mathrm{~B}_{1}=4 \mathrm{~kg} \mathrm{~B} \mathrm{ha}{ }^{-1}, \mathrm{~B}_{2}=6 \mathrm{~kg} \mathrm{~B} \mathrm{ha}^{-1}, \mathrm{~B}_{3}=8 \mathrm{~kg} \mathrm{~B}$ ha ${ }^{-1}$

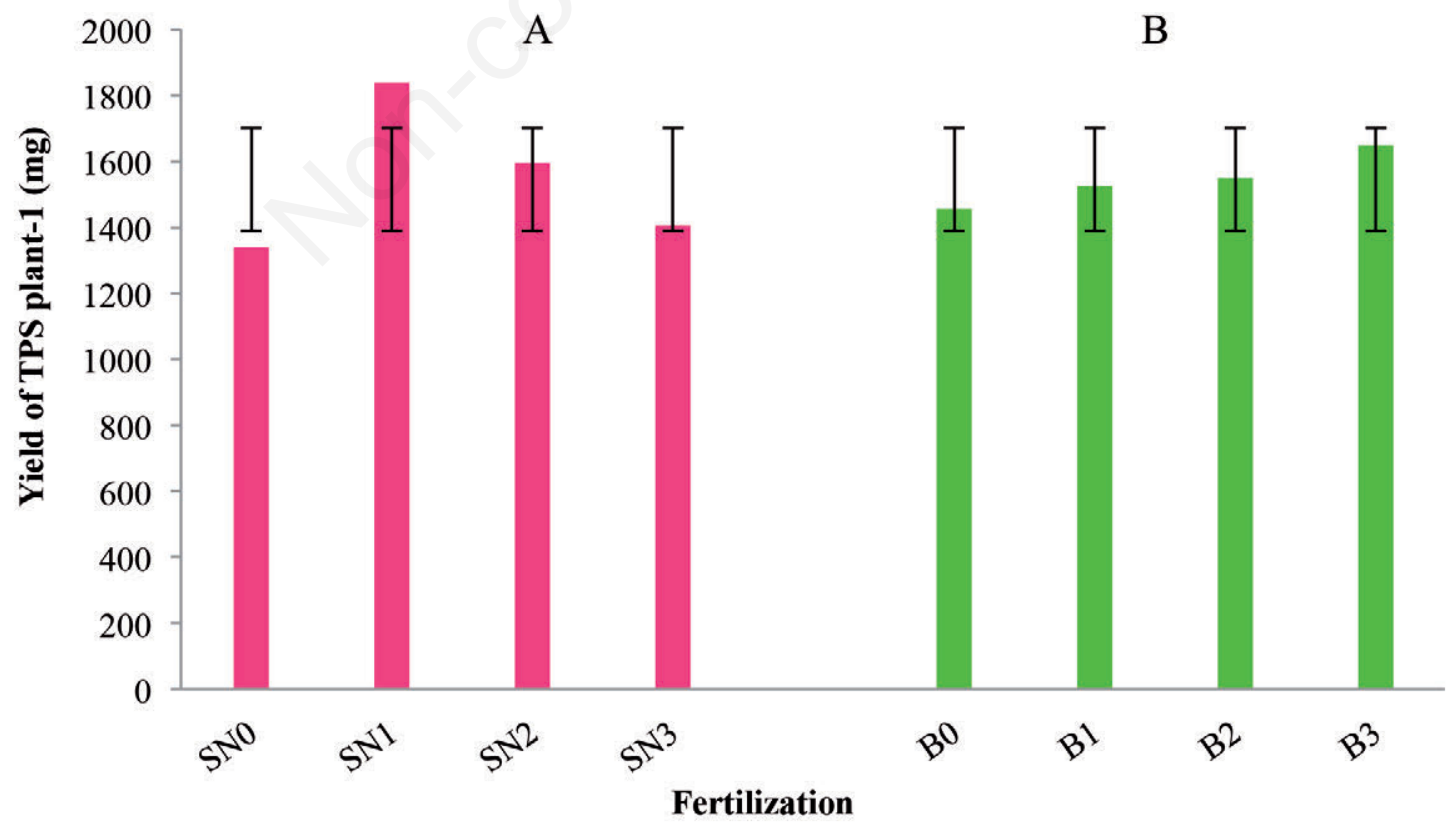

Figure 5. Effect of nitrogen splitting (A) and boron (B) on total yield of TPS plant ${ }^{-1}(\mathrm{mg})$ of potato mother plant (LSD value 10.13 and 129.31 for $\mathrm{SN}$ and $\mathrm{B}$, respectively). $\mathrm{SN}_{0}=2$ split dose (conventional); $\mathrm{SN}_{1}=3$ split dose; $\mathrm{SN}_{2}=4$ split dose; $\mathrm{SN}_{3}=5 \mathrm{split}$ dose; $\mathrm{B}_{0}=0 \mathrm{~kg} \mathrm{~B}$ $\mathrm{ha}^{-1}, \mathrm{~B}_{1}=4 \mathrm{~kg} \mathrm{~B} \mathrm{ha}^{-1} ; \mathrm{B}_{2}=6 \mathrm{~kg} \mathrm{~B} \mathrm{ha}^{-1} ; \mathrm{B}_{3}=8 \mathrm{~kg} \mathrm{~B} \mathrm{ha}^{-1}$. 


\section{Total yield of TPS $\left(\mathrm{kg} \mathrm{ha}^{-1}\right)$}

Split application of $\mathrm{N}$ showed a significant $(\mathrm{p} \leq 0.01)$ difference on the total yield of TPS ( $\mathrm{kg} \mathrm{ha}^{-1}$ ) (Figure 6A). A gradual decreasing trend was found with the increasing split doses of N. The maximum TPS yield (147.09 $\mathrm{kg} \mathrm{ha}^{-1}$ ) was found from $\mathrm{SN}_{1}$ followed by $\mathrm{SN}_{2}(127.59 \mathrm{~kg})$ and the minimum $\left(107.20 \mathrm{~kg} \mathrm{ha}^{-1}\right)$ was in $\mathrm{SN}_{0}$. $\mathrm{Raj}^{26}$ reported that the application of nitrogen $\left(150 \mathrm{~kg} \mathrm{ha}^{-1}\right)$ at 3time or 4-time as splitting produced the highest grain yield of canola. The present result was in agreement with this report. A remarkable $(\mathrm{p} \leq 0.05)$ variation was noted among boron levels in respect of the total yield of TPS $\left(\mathrm{kg} \mathrm{ha}^{-1}\right)$ (Figure 6B). A gradual increasing trend was found with the increasing boron levels. The maximum TPS yield $(131.87 \mathrm{~kg})$ was found from $\mathrm{B}_{3}$ which was statistically similar to $\mathrm{B}_{2}(123.95 \mathrm{~kg}), \mathrm{B}_{1}(121.97 \mathrm{~kg})$ and the minimum $(116.53 \mathrm{~kg})$ was in $\mathrm{B}_{0}$. Dordas ${ }^{27}$ reported that boron is highly required for seed production than forage production in alfalfa which supported the result of present study. Significant $(\mathrm{p} \leq 0.01)$ variation was found among different combinations of split application of $\mathrm{N}$ and boron in respects of the total yield of TPS $\left(\mathrm{kg} \mathrm{ha}^{-1}\right)$ (Table 3$)$. The maximum yield $(172.81 \mathrm{~kg})$ of TPS was found from $\mathrm{SN}_{1} \mathrm{~B}_{3}$ and the minimum $(80.14 \mathrm{~kg})$ was in $\mathrm{SN}_{0} \mathrm{~B}_{0}$.

\section{Weight of 100-TPS (mg)}

Weight of 100-TPS (mg) was significantly ( $\mathrm{p} \leq 0.01)$ influenced by different $\mathrm{N}$ splitting doses (Figure 7A). A gradual increasing trend was found with the increasing split doses of $\mathrm{N}$ up to $\mathrm{SN}_{3}$. The max-

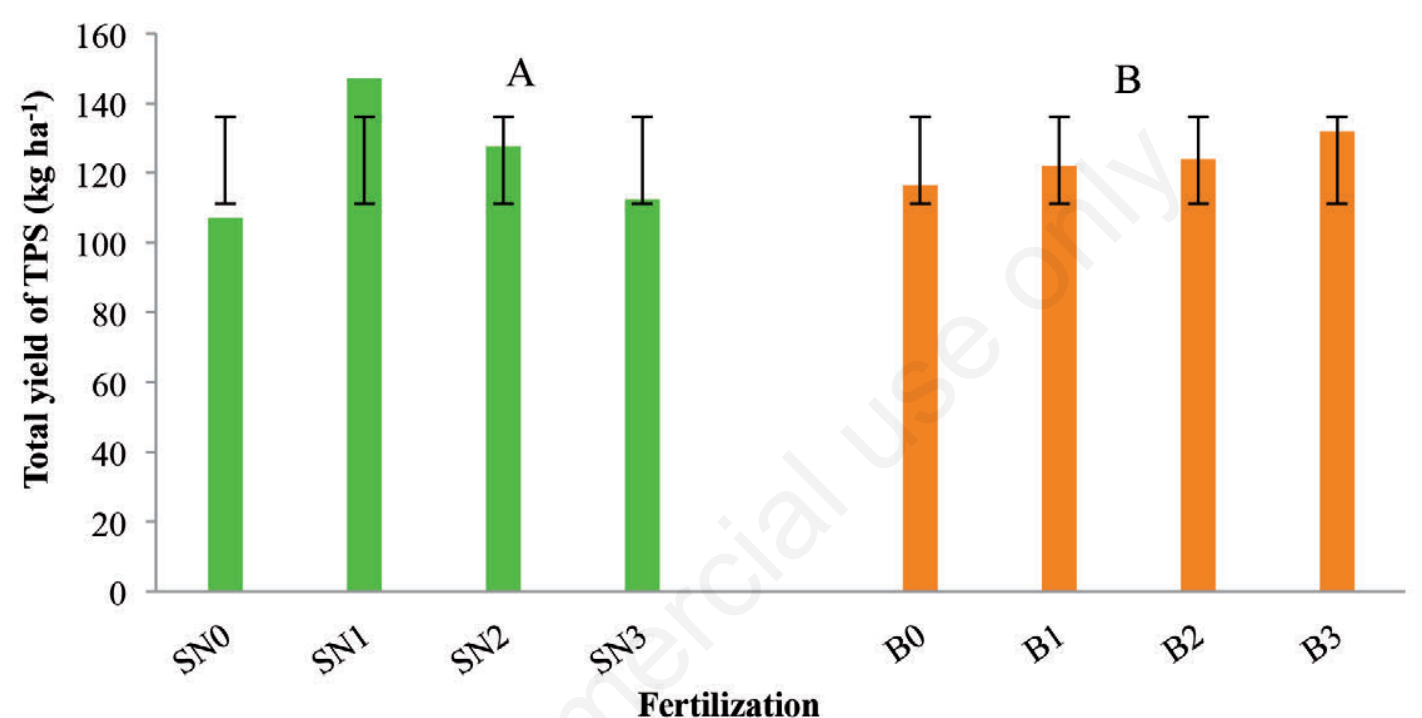

Figure 6. Effect of nitrogen splitting (A) and boron (B) on total yield of TPS $\left(\mathrm{kg} \mathrm{ha}^{-1}\right)$ of potato mother plant (LSD value 0.81 and 10.34 for $S N$ and $B$, respectively). $S N_{0}=2$ split dose (conventional); $S N_{1}=3$ split dose; $S_{2}=4$ split dose; $S N_{3}=5$ split dose; $B_{0}=0$ kg $B$ ha ${ }^{-1} ; B_{1}=4$ $\mathrm{kg} \mathrm{B} \mathrm{ha}{ }^{-1} ; B_{2}=6 \mathrm{~kg} \mathrm{~B} \mathrm{ha}^{-1} ; \mathrm{B}_{3}=8 \mathrm{~kg} \mathrm{~B} \mathrm{ha}^{-1}$.

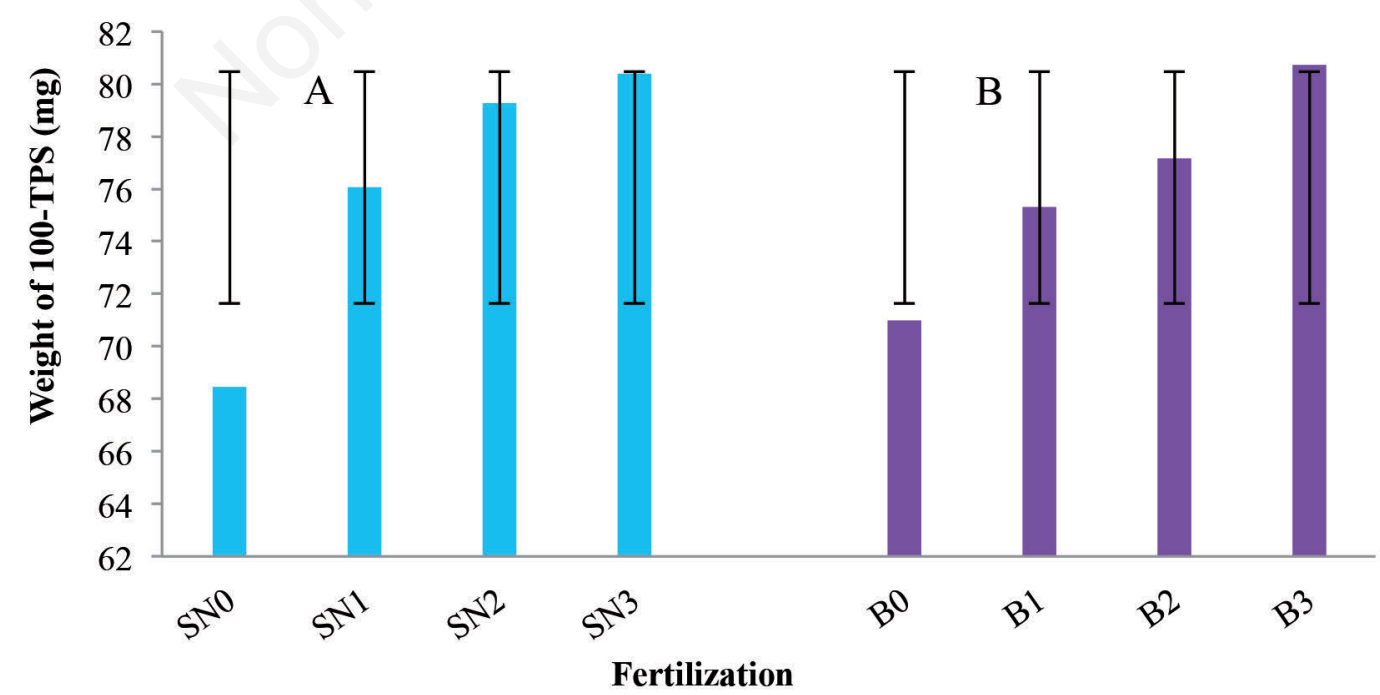

Figure 7. Effect of nitrogen splitting (A) and boron (B) on weight of 100-TPS (mg) of potato mother plant (LSD value 0.31 and 5.01 for $S N$ and $B$, respectively). $S N_{0}=2$ split dose (conventional); $S_{1}=3$ split dose; $S_{2}=4$ split dose; $S_{3}=5$ split dose; $B_{0}=0$ kg $B a^{-1} ; B_{1}=4$ $\mathrm{kg} \mathrm{B} \mathrm{ha}^{-1} ; \mathrm{B}_{2}=6 \mathrm{~kg} \mathrm{~B} \mathrm{ha}^{-1} ; \mathrm{B}_{3}=8 \mathrm{~kg} \mathrm{~B} \mathrm{ha}^{-1}$. 
imum TPS weight $\left(80.38 \mathrm{mg}\right.$ ) was found from $\mathrm{SN}_{3}$ followed by $\mathrm{SN}_{2}$ $(79.26 \mathrm{mg})$ and the minimum $(68.45 \mathrm{mg})$ was in $\mathrm{SN}_{0}$. $\mathrm{Singh}^{28}$ mentioned that seeds those are weightier than $75 \mathrm{mg}$ of 100-TPS showed good quality for raising seedling tuber from TPS. The present study advocated that the weight of 100-TPS was increased with the increase of nitrogen splitting levels. Such result happened probably due to the fact that delay in senescence caused by split nitrogen of application which allowed enough time for berries to receive photosynthates until the last stage of development. ${ }^{3}$ So, nitrogen should be applied at $\mathrm{SN}_{2}$ and $\mathrm{SN}_{3}$ which partially supported the present findings. Significant $(\mathrm{p} \leq 0.01)$ variation was noted among boron doses in respect of the weight of 100-TPS (mg) (Figure 7B). The weight was increased with the increasing of boron level. The maximum TPS weight $\left(80.72 \mathrm{mg}\right.$ ) was found from $\mathrm{B}_{3}$ which was statistically similar to $\mathrm{B}_{2}(77.16 \mathrm{mg})$ and the minimum $(70.98 \mathrm{mg})$ was in $\mathrm{B}_{0}$. Active partitioning of photosynthates and greater accumulation of food reserves in seed resulted higher 1000-seed weight from boron application. ${ }^{29}$ Foliar application of B could increase the seed weight (100grain weight) than those without B on treatment given water in soybean. ${ }^{30}$ Profound $(\mathrm{p} \leq 0.05)$ variation was noted among different combinations of split application of $\mathrm{N}$ and boron in respects of the weight of 100-TPS (mg) from potato mother plant (Table 3 ). The maximum weight of 100-TPS $\left(86.87 \mathrm{mg}\right.$ ) was found from $\mathrm{SN}_{3} \mathrm{~B}_{3}$ which was statistically similar to $\mathrm{SN}_{2} \mathrm{~B}_{3}(84.24 \mathrm{mg}), \mathrm{SN}_{2} \mathrm{~B}_{2}(82.04$ $\mathrm{mg}), \mathrm{SN}_{3} \mathrm{~B}_{1}(79.94 \mathrm{mg})$ and $\mathrm{SN}_{3} \mathrm{~B}_{0}(78.16 \mathrm{mg})$; whereas, the minimum (53.36 mg) was in $\mathrm{SN}_{0} \mathrm{~B}_{0}$.

\section{Pearson correlation coefficient ( $r$ )}

Correlation analysis showed a significant positive relationship among 100-TPS weight, number of TPS berry ${ }^{-1}$ of larger size and total yield of TPS $\left(\mathrm{kg} \mathrm{ha}^{-1}\right)$. A positive relation $\left(\mathrm{r}=0.83\right.$ and $\left.\mathrm{R}^{2}=0.69\right)$ was found between 100-TPS weight (mg) and the number of TPS berry ${ }^{-1}$ of larger size (Figure 8A). That may be due to higher partitioning of nitrogen in berry through the split application. A strong linear relation $(\mathrm{r}=0.88$ and $\left.\mathrm{R}^{2}=0.68\right)$ was found between the total yield of TPS $\left(\mathrm{kg} \mathrm{ha}^{-1}\right)$ and the number of TPS berry ${ }^{-1}$ of larger size (Figure 8B).

\section{Conclusions}

It may be concluded that nitrogen splitting and boron exhibited the significant performances on most the traits studied under present experiments. The maximum yield of TPS plant ${ }^{-1}$ was found from $\mathrm{SN}_{1} \mathrm{~B}_{3}(2160.1 \mathrm{mg})$ and the minimum yield was found from $\mathrm{SN}_{0} \mathrm{~B}_{0}(1001.8 \mathrm{mg})$. The maximum yield of TPS ha- $\mathrm{has}^{-1}$ wand from $\mathrm{SN}_{1} \mathrm{~B}_{3}(172.81 \mathrm{~kg})$ and the minimum yield was found from $\mathrm{SN}_{0} \mathrm{~B}_{0}(80.14 \mathrm{~kg})$. But, the weight of 100 -TPS was found maximum from $\mathrm{SN}_{3} \mathrm{~B}_{3}(86.87 \mathrm{mg})$; whereas, the $\mathrm{SN}_{0} \mathrm{~B}_{0}$ showed the minimum weight. In conclusion, the combination of $\mathrm{SN}_{1} \mathrm{~B}_{3}$ (3 split applications of $\mathrm{N}$ and $8 \mathrm{~kg} \mathrm{~B} \mathrm{ha}^{-1}$ ) is best for producing high amount of hybrid TPS from the potato mother plant.
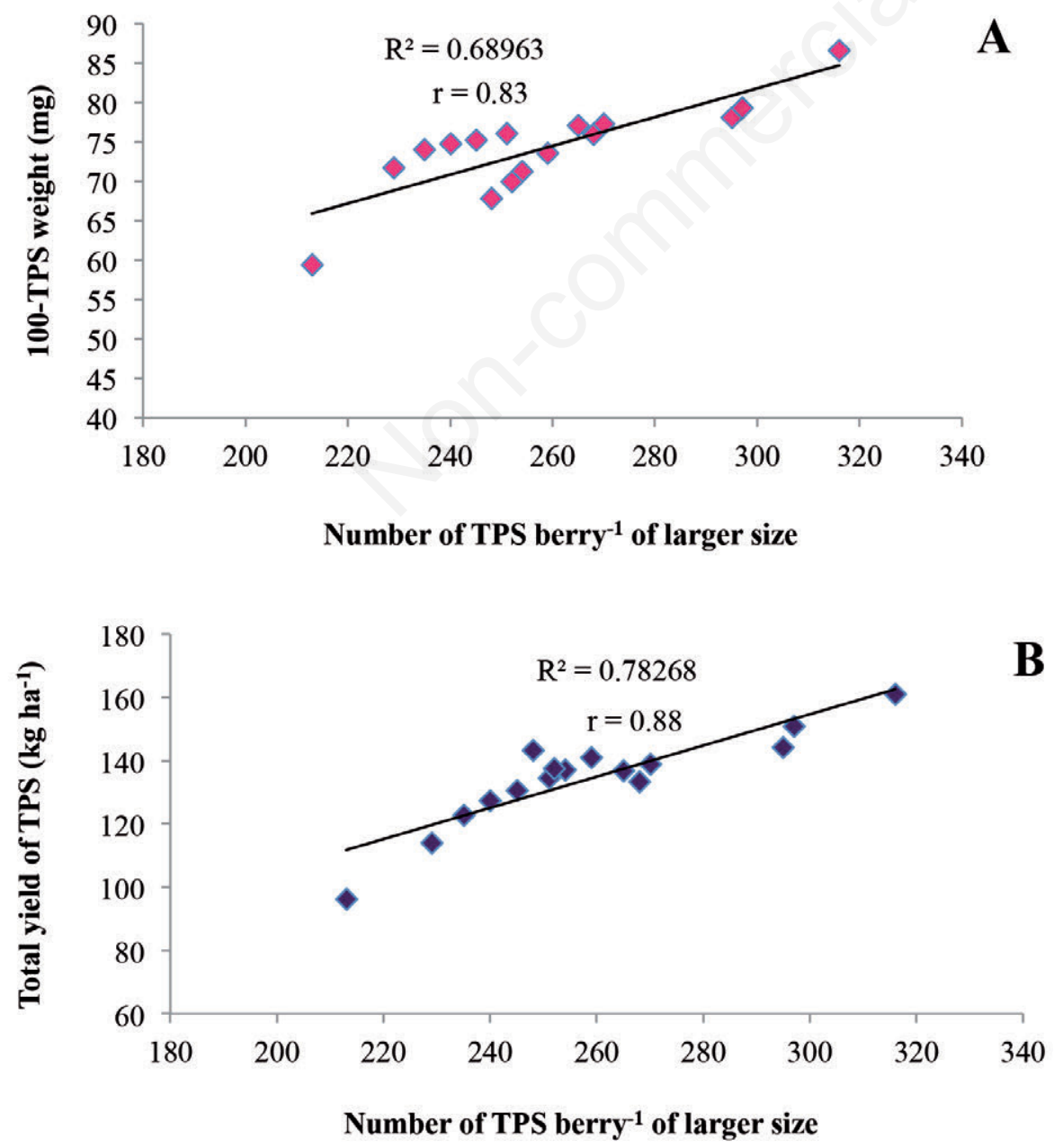

Figure 8. Relation between number of TPS berry ${ }^{-1}$ of larger size, 100-TPS weight (mg) (A) and total yield of TPS $\left(\mathrm{kg} \mathrm{ha}^{-1}\right)$ (B). 


\section{References}

1. FAOSTAT. Statistical Database. Food and Agriculture Organization of the United Nations, Rome, Italy. 2017.

2. Siddique MA, Rashid MH. Role of True Potato Seed in potato development. In: Proc. of the workshop on potato development in Bangladesh, Dhaka, Bangladesh. 2000; pp. 43-8.

3. Pallais N, Villagarcia S, Fong N, Tapia J, Garcia R. Effect of supplemental nitrogen on true potato seed weight. Am Potato J 1987;64:483-1.

4. Maingi DM, Nyabundi JO, Kidane-Mariam HM. The effect of nitrogen fertilizer split application on flowering, berry number and size in true potato (Solanum tuberosum L.) seed production. In: Proc. of the 5th Symp. ISTRC-Africa Branch, Accra, Ghana. 1994, pp. 194-7.

5. Pallais N. True potato seed quality. Theor Appl Genet 1987;73:784-2

6. Dayal TR, Upadhya MD, Chaturvedi SN. Correlation studies on 100-true seed weight, tuber yield and other morphological traits in potato (Solanum tuberosum L.). Potato Res 1984;27:185-8.

7. Grant CA, Wu R, Selles F, Harker KN, Clayton GW, Bittman S, Zebarth BJ, Lupwayi NZ. Crop yield and nitrogen concentration with controlled-release urea and split applications of nitrogen as compared to non-coated urea applied at seeding. Field Crops Res 2012;127:170-0.

8. Rawson HM. The developmental stage during which boron limitation causes sterility in wheat genotypes and the recovery of fertility. Australian J Plant Physiol 1996;2:709-717.

9. Brown PH, Bellaloui N, Wimmer MA, Bassil ES, Ruiz J, Hu H, Pfeffer H, Dannel F, Romheld V. Boron in plant biology. Plant Biol 2002;4:205-3.

10. Agarwala SC, Sharma PN, Chatterjee C, Sharma CP. Development and enzymatic change during pollen development in boron deficiency maize plants. J Plant Nutr 1981;3:329-6.

11. Rerkasem B, Lordkaew S, Dell B. Boron requirement for reproductive development in wheat. Soil Sci Plant Nutr 1997;43:953-7.

12. Naga SK, Swain SK, Sandeep VV, Raju B. Effect of foliar application of micronutrients on growth parameters in tomato (Lycopersicon esculentum Mill.). Discourse J Agril food Sci 2013;1:146-1.

13. Day SC. Tomato crop in vegetable growing. Agrobios, New Dehli, India. 2000; pp. 59-1.

14. Smit JN, Combrink NJJ. Pollination and yield of winter-grown greenhouse tomatoes as affected by boron nutrition, cluster vibration, and relative humidity. South African J Plant Soil 2005;22:110-5.

15. Nonnecke IBL. Vegetable Production. Avi Book Publishers. New York, USA. 1989; pp. 200-9.
16. Phookan DB, Shadeque A, Barukah PJ. Effect of plant growth regulators on seed yield and quality of tomato. Vegetable Sci 1991;18:93-5.

17. Halfacre, RG, Barden, JA. In: Horticulture, McGraw Hill Book.Co. USA. 1979.

18. Stanley DW, Bourne MC, Stone AP, Wismer WV. Low-temperature blanching effects of chemistry, firmness, and structure of canned green beans and carrots. Food Sci 1995;60:327-3.

19. Siddique MNA, Sultana J, Huda MS, Abdullah MR, Chowdury MA. Potato production and management with preference to seed potato supply chain, certification and, sectors involved in Bangladesh. Intl J Business Manag Soc Res 2015;1:1-3.

20. UNDP. Land Resources Appraisal of Bangladesh for Agricultural Development. Report 2. Agroecological Regions of Bangladesh. United Nations Development Programme and the Food and Agriculture Organization. 1988; pp. 212-1.

21. Thakur KC, Upadhya MD. Strategies for the transfer of hybrid TPS production technology. In: Production and Utilization of True Potato Seed in Asia. Proc. Inter-Regional Workshop held at the Central Potato Research Station, Modipuram, India. 1996; pp. 135-5.

22. Moniruzzaman AFM. A survey report on the response of farmers to potato production from True Potato Seed (TPS). Bangladesh Agricultural Research Institute, Gazipur, Bangladesh. 2000; pp. 1-4.

23. Gomez KA, Gomez AA. The statistical procedure of agricultural research. 2nd Edition. John Willey and Sons, New York, USA. 1984; p. 188.

24. Roy TS, Nishizawa T, Ali MH. Flower, berry and true potato seed production in potato mother plants (Solanum tuberosum L.). 1. Effects of nitrogen and phosphorus fertilizers. J Agron 2007a;6:106-2.

25. Almekinders CJM, Struik PC. Shoot development and flowering in potato (Solanum tuberosum L.). Potato Res 1996;39:581-7.

26. Raj M. Canola response to split nitrogen applications at Katanning. Annual report. Department of Agriculture and Food, Western Australia. 2013; p. 1.

27. Dordas C. Foliar boron application improves seed set, seed yield, and seed quality of alfalfa. Agron J 2006;98:907-3.

28. Singh J, Singh AN, Pandey PC. True potato seed for potato production in India. Technical Bulletin No. 24, Central Potato Research Institute, Indian Council for Agricultural Research, India. 1990; pp. 13-4.

29. Hamsaveni MR, Kurdikeri MB, Shekhargouda M, Shashidhara SD, Dharmatti PR. Effect of Gypsum and Boron on Seed Yield and Quality on Tomato Cv. Megha. Karnataka J Agric Sci 2010;16:25-2.

30. Bellaloui N, Hu Y, Mengistu A, Kassem MA, Abel CA. Effects of foliar boron application on seed composition, cell wall boron, and seed $\delta 15 \mathrm{~N}$ and $\delta 13 \mathrm{C}$ isotopes in water-stressed soybean plants. Front Plant Sci 2013;4:270. 